\title{
Usability of Telemedicine Mobile Applications during COVID-19 in Saudi Arabia: A Heuristic Evaluation of Patient User Interfaces
}

\author{
Raniah N. Aldekhyyel ${ }^{*}{ }^{\dagger}$, Jwaher A. Almulhem ${ }^{\dagger}$ and Samar Binkheder (D) \\ Medical Informatics and e-Learning Unit, Medical Education Department, College of Medicine, King Saud \\ University, Riyadh 11451, Saudi Arabia; jalmulhem@ksu.edu.sa (J.A.A.); sbinkheder@ksu.edu.sa (S.B.) \\ * Correspondence: raldekhyyel@ksu.edu.sa \\ + Authors have equal contribution to this manuscript.
}

check for

updates

Citation: Aldekhyyel, R.N.;

Almulhem, J.A.; Binkheder, S.

Usability of Telemedicine Mobile

Applications during COVID-19 in

Saudi Arabia: A Heuristic Evaluation

of Patient User Interfaces. Healthcare

2021, 9, 1574. https://doi.org/

$10.3390 /$ healthcare 9111574

Academic Editor: Daniele Giansanti

Received: 14 October 2021

Accepted: 16 November 2021

Published: 18 November 2021

Publisher's Note: MDPI stays neutral with regard to jurisdictional claims in published maps and institutional affiliations.

Copyright: (C) 2021 by the authors. Licensee MDPI, Basel, Switzerland. This article is an open access article distributed under the terms and conditions of the Creative Commons Attribution (CC BY) license (https:/ / creativecommons.org/licenses/by/ $4.0 /)$.

\begin{abstract}
The coronavirus disease 2019 (COVID-19) pandemic has impacted the use of telemedicine application (apps), which has seen an uprise. This study evaluated the usability of the user interface design of telemedicine apps deployed during the COVID-19 pandemic in Saudi Arabia. It also explored changes to the apps' usability based on the pandemic timeline. Methods: We screened ten mHealth apps published by the National Digital Transformation Unit and selected three telemedicine apps: (1) governmental "Seha" ${ }^{\circledR}$ app, (2) stand-alone “Cura" ${ }^{\circledR}$ app, and (3) private "Dr. Sulaiman Alhabib" ${ }^{\circledR}$ app. We conducted the evaluations in April 2020 and in June 2021 by identifying positive app features, using Nielsen's ten usability heuristics with a five-point severity rating scale, and documenting redesign recommendations. Results: We identified 54 user interface usability issues during both evaluation periods: 18 issues in "Seha" 14 issues in "Cura", and 22 issues in "Dr. Sulaiman Alhabib". The two most heuristic items violated in "Seha", were "user control and freedom" and "recognition rather than recall". In "Cura", the three most heuristic items violated were "consistency and adherence to standards", "esthetic and minimalist design", and "help and documentation" In "Dr. Sulaiman Alhabib" the most heuristic item violated was "error prevention". Ten out of the thirty usability issues identified from our first evaluation were no longer identified during our second evaluation. Conclusions: our findings indicate that all three apps have a room for improving their user interface designs to improve the overall user experience and to ensure the continuity of these services beyond the pandemic.
\end{abstract}

Keywords: telemedicine; mHealth; heuristic evaluation; usability; Saudi Arabia; COVID-19

\section{Introduction}

The coronavirus disease 2019 (COVID-19) pandemic has negatively impacted the world on different dimensions. The virus has spread rapidly with more than 196 million confirmed cases as of the 1st of August 2021 [1]. The threat of an imminent surge of COVID19 patients drove healthcare organizations to act quickly to develop and deploy mobile health technologies $[2,3]$, with telemedicine solutions in particular seeing an uprise $[2,4,5]$. Like other countries, healthcare organizations in Saudi Arabia responded to the pandemic by creating strategies to control the spread of disease, including the use of mHealth apps to provide telemedicine care for their patients [6,7]. While many studies have shown the benefits of telemedicine apps on patients and providers [2], the usability of these apps needs to be addressed more fully [8].

Ensuring excellent usability is at the core of patient engagement [9]. Given the rapid increase in telemedicine apps during the pandemic and insufficient usability assessments, the potential impacts on user engagement and experience are not clear but are substantial [10]. Performing standardized usability assessments designed to capture the user's experience with telemedicine apps is critical in ensuring a positive user experience. Usability is defined by the International Organization for Standardization (ISO) as "the extent to which 
the product can be used by specified users to achieve specified goals with effectiveness, efficiency, and satisfaction in a specified context of use." [11]. Usability is considered as a vital measure that captures users' experience and helps inform the design of mHealth apps [12]. Researchers can use several methods to evaluate usability, including the heuristic evaluation method, involving several experts examining the system's interface design [13]. Heuristic evaluation has been used extensively by different researchers [14-18] due to its low cost, ease of use, and the involvement of a small number of experts [19,20].

Saudi Arabia has many advances in digital healthcare, with specific strategic plans put in place for the advancement of healthcare using information technology [21]. Changes in insurance policies announced by the Saudi Council of Cooperative Health Insurance [22] during the pandemic indicating that telemedicine services would be covered by insurance companies influenced the rapid deployment of telemedicine services. While the effectiveness of telemedicine care has been published in the literature [23], with specific studies focusing on telemedicine user satisfaction during the pandemic [24-27], little is known about the ease and usability of telemedicine apps [8].

In this study our goal was to complete a heuristic evaluation to assess the usability of telemedicine apps, deployed in Saudi Arabia during the pandemic. We conducted the usability evaluation using Jakob Nielsen's 10 usability heuristics for interface design [13]. We also explored changes to the usability of apps based on the pandemic timeline through conducting the evaluation during two different time periods.

\section{Materials and Methods}

We followed three phases in our study: Phase I was selecting telemedicine apps, Phase II was conducting the heuristic evaluation during two different time periods, and Phase III was data analysis. We conducted the first evaluation one month after announcing the first COVID-19 case in Saudi Arabia [28], and the country's lockdown during April 2020, while the second evaluation was 14 months after our first evaluation (June 2021). We followed the same heuristic evaluation process during both evaluation periods.

\subsection{Phase I. Telemedicine Apps Selection}

In line with the government lockdown measures, the Saudi National Digital Transformation (NDT) Unit [29] during the time of our study published a document outlining a total of 10 mHealth apps (Appendix A, Table A1). On the 11th of April 2020, we independently reviewed the document and selected apps that met the criteria of a telemedicine mobile app, based on the definition of "telemedicine" as outlined in the National Saudi Telemedicine Policy: "mobile applications that provide remote interaction between a patient and a healthcare provider delivered through video, and/or audio, and/or picture, and/or text, and/or data" [30]. Any mHealth app, which did not include a telemedicine feature, such as apps developed for medication delivery, medical encyclopedias, or patient portals were excluded from our evaluation The three apps we selected covered three main types of telemedicine services; (1) the governmental app "Seha" ${ }^{\circledR}$ [7], (2) the stand-alone private app "Cura" ${ }^{\circledR}[31]$, and (3) a private app called "Dr. Sulaiman Alhabib" ${ }^{\circledR}$, which is a paid telemedicine service provided by a private hospital [32].

\section{Apps Description}

"Seha" app provides free telemedicine consultation services for all citizens and residents. Users are required to register in the app using their mobile number. Once registration is confirmed through a text message sent to the user's mobile, users can request for a consultation with a Ministry of Health's physician up to three times per month. The app is not linked to a certain hospital/clinic nor to a specific unified patient medical record number. The app also includes an artificial intelligence technology feature in the form of an automatic health assessment tool.

"Cura" app is a stand-alone telemedicine app providing a paid consultation service to its users. The app offers on-demand consultations with general practitioners, specialists, 
and consultants. Users can choose a consultation with a specific physician from viewing a list of available physicians. The app also offers different wellness program packages. Like "Seha", users register once using their mobile number and receive a confirmation through a text message. Consultations are offered with a fee that users are required to pay in advance. The app is not linked to a certain hospital/clinic or a specific unified patient medical record number.

"Dr. Sulaiman Alhabib" app is developed by Dr. Sulaiman Al Habib Medical Group; a private hospital with over 10 branches in Saudi Arabia. The app provides a variety of services for the hospitals' patients and is integrated with their medical record system. The app provides a wide range of services for patients. Telemedicine consultation feature was added during the early months COVID-19 pandemic in 2020. The number of consultations offered to its users is based on their specific insurance coverage.

\subsection{Phase II. Evaluation Procedure}

To conduct the usability evaluation, we used Jakob Nielsen's 10 usability heuristics for interface design [13,33] due to their widespread use [14-18]. After we performed an unstructured qualitative overview of the three apps, we designed an online form using google forms [34], which contained two sections: (1) features of the apps using a yes/no nominal scale, and (2) Nielsen's ten usability heuristics with a 5-point severity rating scale [35] (Appendix B).

Given that we have no affiliation with the organizations, which developed the apps included in our study, and our background in health informatics and experience in usability testing and evaluation methodologies, we conducted the evaluation ourselves. Before each evaluation, we briefly discussed the heuristics and the severity classification to ensure that we followed a standardized evaluation process. Each of us then installed the three apps on our personal mobile phones (iPhone 11) and registered to access the apps. Using the standardized online form, we independently reviewed the apps and completed a real time teleconsultation with a physician to identify compliance with the heuristics. We completed separate forms to identify the apps' features, record issues related to the heuristics, provide descriptions, and assign the severity ratings, and record the location of the issues.

\subsection{Phase III. Data Analysis}

Following the evaluation, we compiled the forms into a single form, and together we discussed our findings, generated consensus ratings, and provided redesign recommendations. We calculated frequencies and percentages for the usability issues and assigned the location of the issues to one of the following categories: (1) registration, (2) $\log$ in, (3) orientation on how to use the app, (4) initiating a consultation, (5) waiting for physician (6) during consultation, and (7) end of consultation. We identified the categories based on the steps users would follow to complete a consultation with a physician through the apps.

After completing both evaluations, we further analyzed our findings by examining the usability issues resulting from the first evaluation to check if they were still an issue in our second evaluation or were they resolved.

To avoid bias, we followed the recommendations outlined by McDonagh et. al in selecting studies for review [36], specifically: (1) defining an inclusion and exclusion criteria, and (2) applying dual review during the selection and evaluation phases-having two evaluators independently assess mhealth apps for inclusion and evaluate the apps using Nielsen's ten usability heuristics. The same evaluators conducted both evaluations and none were affiliated with the organizations responsible for developing the apps.

\section{Results}

Table 1 shows an overview of the features of the three apps. 
Table 1. Apps Features.

\begin{tabular}{|c|c|c|c|c|c|c|}
\hline \multirow{2}{*}{ Feature } & \multicolumn{2}{|c|}{ "Seha" } & \multicolumn{2}{|c|}{ "Cura" } & \multicolumn{2}{|c|}{$\begin{array}{l}\text { "Dr. Sulaiman } \\
\text { Al Habib" }\end{array}$} \\
\hline & 2020 & 2021 & 2020 & 2021 & 2020 & 2021 \\
\hline $\begin{array}{l}\text { Ability to access educational } \\
\text { information on COVID-19 }\end{array}$ & $\sqrt{ }$ & $\sqrt{ }$ & $\sqrt{ }$ & $\times$ & $\times$ & $\times$ \\
\hline $\begin{array}{l}\text { Includes COVID-19 patient } \\
\text { self-assessment tool }\end{array}$ & $\sqrt{ }$ & $\times$ & $\times$ & $\times$ & $\times$ & $\times$ \\
\hline $\begin{array}{l}\text { Limit to number of } \\
\text { patient consultations }\end{array}$ & $\sqrt{ }$ & $\sqrt{ }$ & $\sqrt{ }$ & $x^{+}$ & $x^{+}$ & $x^{+}$ \\
\hline $\begin{array}{l}\text { Patient able to choose among } \\
\text { physician specialties }\end{array}$ & $\times$ & $\times$ & $\sqrt{ }$ & $\sqrt{ }$ & $\sqrt{ }$ & $\sqrt{ }$ \\
\hline $\begin{array}{l}\text { Patient able to see } \\
\text { physician details }\end{array}$ & $\sqrt{ }$ & $\sqrt{ }$ & $\sqrt{ }$ & $\sqrt{ }$ & $\sqrt{ }$ & $\sqrt{ }$ \\
\hline Supports video call & $\sqrt{ }$ & $\sqrt{ }$ & $\sqrt{ }$ & $\sqrt{ }$ & $\sqrt{ }$ & $\sqrt{ }$ \\
\hline Supports text messaging & $\sqrt{ }$ & $\sqrt{ }$ & $\sqrt{ }$ & $\sqrt{ }$ & $\times$ & $\sqrt{ }$ \\
\hline Supports voice messaging & $\sqrt{ }$ & $\sqrt{ }$ & $\sqrt{ }$ & $\sqrt{ }$ & $\times$ & $\times$ \\
\hline Ability to attached and send files & $\sqrt{ }$ & $\sqrt{ }$ & $\sqrt{ }$ & $\sqrt{ }$ & $\times$ & $\times$ \\
\hline $\begin{array}{l}\text { Patient able to schedule a } \\
\text { telemedicine consultation }\end{array}$ & $\sqrt{ }$ & $\sqrt{ }$ & $\sqrt{ }$ & $\sqrt{ }$ & $\times$ & $\sqrt{ }$ \\
\hline $\begin{array}{l}\text { Patient able to receive on } \\
\text { demand consultation }\end{array}$ & $\sqrt{ }$ & $\sqrt{ }$ & $\sqrt{ }$ & $\sqrt{ }$ & $\sqrt{ }$ & $\sqrt{ }$ \\
\hline $\begin{array}{l}\text { Physician able to order } \\
\text { a prescription }\end{array}$ & $\sqrt{ }$ & $\sqrt{ }$ & $\sqrt{ }$ & $\sqrt{ }$ & $\sqrt{ }$ & $\sqrt{ }$ \\
\hline Linked to patient medical record & $\times$ & $\times$ & $\times$ & $\times$ & $\sqrt{ }$ & $\sqrt{ }$ \\
\hline $\begin{array}{l}\text { Patient able to view } \\
\text { past consultation }\end{array}$ & $\sqrt{ }$ & $\sqrt{ }$ & $\sqrt{ }$ & $\sqrt{ }$ & $\sqrt{ }$ & $\sqrt{ }$ \\
\hline End with satisfaction survey & $\sqrt{ }$ & $\sqrt{ }$ & $\sqrt{ }$ & $\sqrt{ }$ & $\sqrt{ }$ & $\sqrt{ }$ \\
\hline
\end{tabular}

+ Depends on each user's insurance coverage plan.

A summary of the usability issues identified in "Seha", "Cura", and "Dr. Sulaiman Alhabib" apps during the two evaluation periods, with the location of issues, severity rating, and redesign recommendations are presented in Tables A2-A4 respectively (Appendix C). In total, we identified 54 user interface usability issues during both evaluation periods: 18 issues in "Seha" app (9 from the first and 9 from the second), 14 issues in "Cura" app (9 from the first and 5 from the second), and 22 issues in "Dr. Sulaiman Alhabib" app (12 from the first and 10 from the second). In "Seha" app, the two most heuristic items violated were "user control and freedom" and "recognition rather than recall", with three unique usability issues identified in each. We found no issues under the "recognition diagnosis, and recovery from errors" heuristic. In "Cura" app the three most heuristic items violated were "consistency and adherence to standards", "esthetic and minimalist design", and "help and documentation", with three unique usability issues identified in each. We found no issues under the two heuristics: "visibility of system status" and "recognition diagnosis, and recovery from errors". In "Dr. Sulaiman Alhabib" app the most heuristic item violated was "error prevention", with four unique usability issues identified, followed by "user control and freedom", and help and documentation", with three unique usability issues identified in each. The "flexibility and efficiency of use" heuristic item among all apps did not include accelerators or an ability to tailor frequent actions based on inexperienced and experienced users, therefore we considered this item not applicable in our evaluation.

Based on the location of issues among the three apps, we found the most usability issues were during the "consultation initiation" $(n=21)$, followed by "orientation" $(n=9)$, 
"during consultation" $(n=7)$, "registration" $(n=5)$, and "login" $(n=5)$. The least number of issues were categorized as "waiting for physician" $(n=4)$, and "end of consultation $(n=3)$. Notably, results of our first evaluation showed two location categories: "orientation" and "consultation initiation" related to the nine usability issues identified in "Cura" app. The only five usability issues categorized as "registration" were found in "Dr. Sulaiman Alhabib" app, and the only four usability issues categorized as "waiting for physician" were identified in "Seha" app.

When we compared between the two evaluation periods, the numbers of usability issues in "Seha" app were similar in both evaluations, however the average severity rating was slightly higher in the second evaluation. In "Cura" app, the number of usability issues in the second evaluation was lower while the average severity rating was considerably higher in the second evaluation compared to the first evaluation. Average severity ratings for the "Dr. Sulaiman Alhabib" app was slightly changed between both evaluations while the number of usability issues was higher in the first evaluation in contrast to the second evaluation (Figure 1).

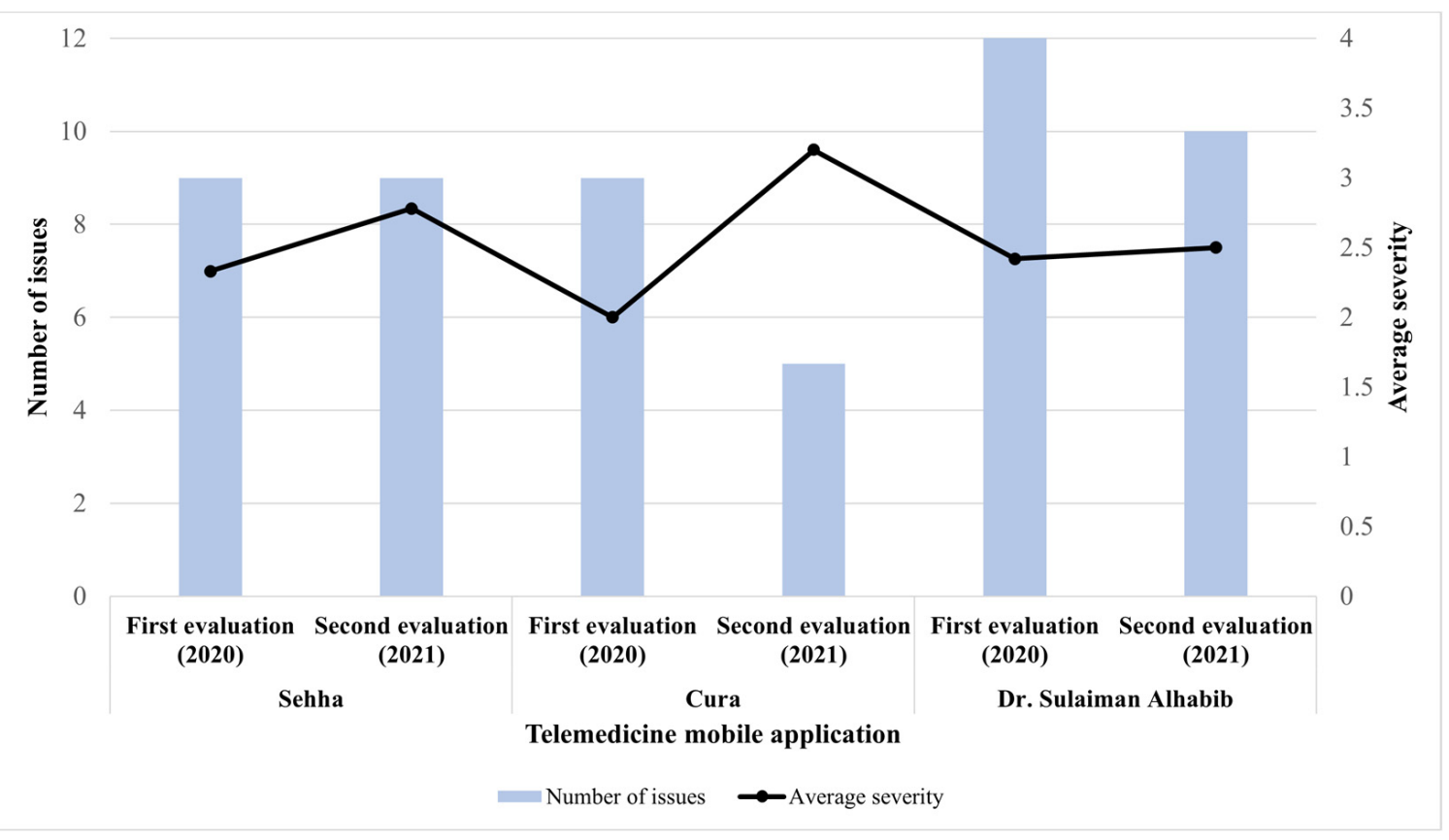

Figure 1. Frequency and average severity ratings by evaluation period among the three apps.

The average severity ratings based on the heuristics in "Seha" app, showed two catastrophic issues: "error prevention" (identified from the first evaluation), and "help and documentation" (identified from the second evaluation). In the "Cura" app, issues related to both "consistency and standards" and "error prevention" items were rated as major issues in the first evaluation. Notably, five out of ten heuristic items did not involve any usability issues in the second evaluation. In "Dr. Sulaiman Alhabib" app, issues related to "recognition rather than recall" and "help and documentation" were rated as catastrophic in the first evaluation and issues related to "error prevention" were rated as catastrophic in the second evaluation (Figure 2).

Our first evaluation resulted in the discovery of 30 user interface usability issues among the three apps, with 10 of these issues no longer identified from our second evaluation. Three out of nine issues in both "Seha" and "Cura" apps were resolved, while four out of 12 issues were resolved in "Dr. Sulaiman Alhabib" app (Tables A2-A4 Appendix C). 

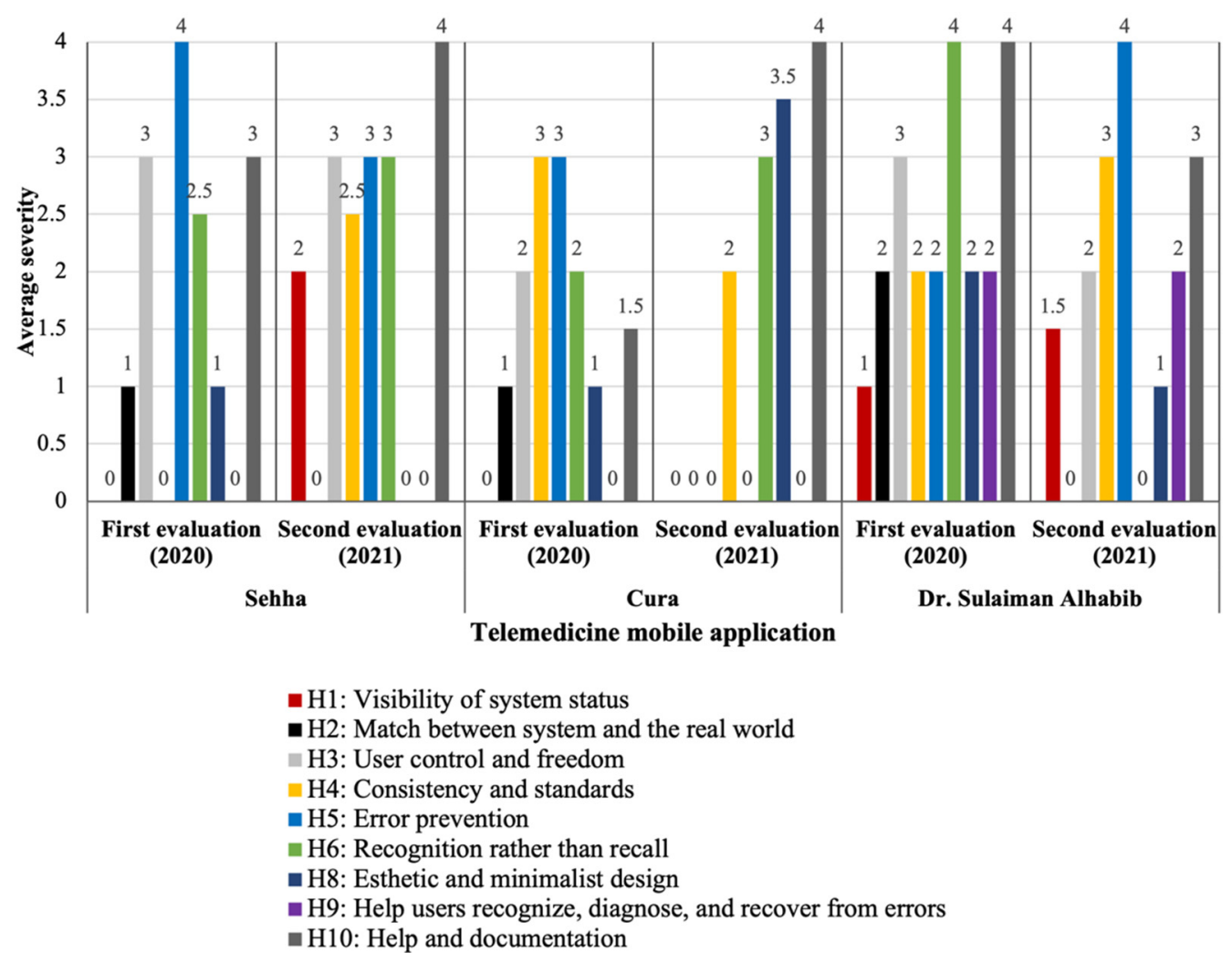

Figure 2. Average severity ratings by heuristic items among the three apps. H7: Flexibility and efficiency of use is not displayed in the chart.

\section{Discussion}

Several telemedicine apps have been developed in Saudi Arabia ranging from free to paid services in response to the pandemic. With the increased availability of these apps, it is essential to measure the apps' usability from a user's perspective, to ensure continuity of these services beyond the pandemic. Our study was conducted to explore the usability issues related to three telemedicine apps used in Saudi Arabia during the pandemic, using Nielsen's 10 heuristics. We performed two evaluations during two time periods to explore any changes to the usability of apps based on the pandemic timeline. We found that following a standardized approach in identifying the features of the telemedicine apps along with conducting the heuristic evaluation was a feasible and efficient method to evaluate the apps' user interfaces. This method helped highlight positive features as well as classify usability issues, which may potentially assist the apps' developers in resolving issues in future updates. We also used a standardized severity rating score for each issue we identified based on the 10 heuristics items. The rating helped highlight the significant usability issues and prioritize them to allocate possible resources in overcoming these issues $[13,14]$. Our evaluation also suggested possible redesign solutions, which if implemented can potentially enhance the overall user experience.

When developing telemedicine apps, healthcare organizations providing telemedicine services in Saudi Arabia must be aware of the current governing regulations [37-40], and accreditation bodies [41]. During the pandemic many efforts have been made by these organizations to develop and update their regulations to serve as a guide for healthcare organizations and developers. A national online training course for healthcare providers has also recently been launched by the Saudi Commission for Health Specialties to ensure a standardized approach in providing telemedicine care [42]. Utilizing these resources would ensure a high standard of telemedicine care and an overall positive user experience.

Beyond the results of our usability evaluation, our study demonstrated four key findings. First, the "Dr. Sulaiman Alhabib" app was the only app in our study linked to a hospital medical record system. "Seha" and "Cura" apps, which lacked integration 
with a medical record system may potentially affect the overall patient care experience since the medical record represents the main method for documenting the patient's health encounter. The importance of documentation in a patient's record has clearly been outlined in one of the provisions of the Saudi telemedicine regulations [30]. The regulation states that health care providers need to have access to the patient's relevant health information and that all patient's data and activities conducted during a telemedicine encounter be documented in the patient's medical record [43]. A possible solution for this significant concern is incorporating the Shared E-Health File; a unified national electronic system that enables information exchange among different hospitals [44]. Incorporating an access to the Shared E-Health File within telemedicine apps [30] may potentially improve the level of care provided to patients and data interoperability. Specific measures would need to be put in place to overcome the challenges that the unified medical record system and the EHR cloud systems may bring. Challenges such as data protection and security issues are critical challenges for its acceptance among patients and healthcare providers $[45,46]$.

Second, there was a slight difference between the usability issues identified during both evaluations based on the pandemic timeline. Although the number of usability issues were higher during our first evaluation, the average severity ratings for all apps were higher during our second evaluation. This may indicate the developers' efforts in continuously working towards enhancing the users' experience. In both evaluations, there were issues with "help and documentation". Adding a separate accessible page outlining user instruction on how to use the app and access the telemedicine service is vital in enhancing the overall user experience [47]. Without having adequate user instructions, users may find difficulty in using the app, particularly with lack of technical support contact and the different types of users. When developing these apps, several age-related issues should be considered including cognition, perception, and behavior issues [8]. Providing help and support also is needed to overcome some technological barriers such as low technology literacy related to using telemedicine apps [48]. Although the apps we reviewed in our study were overall user friendly, special consideration should be provided to consider experienced and non-experienced users since we found "lack of flexibility" common within all three apps. Enabling users to customize user interfaces and create shortcuts might add a more personalized approach and a positive user experience [16].

Third, the rapid deployment of telemedicine apps in anticipation of a surge in COVID19 cases may explain why we found most of the identified issues categorized as major problems and four out of seven catastrophic usability issues in "Dr. Sulaiman Alhabib" app's user interfaces. "Dr. Sulaiman Alhabib" app's telemedicine service was the only service developed in response to the pandemic and to changes to the country's insurance policies [22]. It remains to be seen whether this service will last beyond the resolution of the pandemic and what role this will have on the use of telemedicine, particularly for their hospital's patients

Lastly, the evaluation process itself resulted in identifying shared user tasks among the three apps. These tasks outlined the steps the user needed to perform to complete a specific telemedicine encounter. The identification of tasks helped us categorize usability issues into structured locations, which could potentially be used for future studies focusing on performing a cognitive walkthrough as a usability evaluation method [49].

Our study has several limitations. First, our app selection process was based on a publication issued by the NDT during the early months of the pandemic. These apps may not have represented the most used apps by the public during the time of our study. Relying on a different source, such as top downloads in App Store or Google Play, could have resulted in other apps included in our evaluation. Second, we conducted a heuristic evaluation, which depends on experts' expertise. While this type of evaluation has proven useful in identifying usability issues, it may not be comprehensive in identifying all difficulties, which may be captured in usability tests with human participants [33]. Conducting a usability user test, which includes both types of users (healthcare providers and patients), considering different age groups may overall enhance the user experience. Lastly, because 
we used a heuristic evaluation method to assess the usability of the user interface, which is considered a method with limited generalizability [50], our study findings may be limited. Utilizing a combination of evaluation methods, such as cognitive walkthroughs and simulated interaction may provide a more comprehensive picture.

\section{Conclusions}

Heuristic evaluation studies have the potential to assist software designers and developers to discover severe usability issues that may have an effect on user acceptance of these apps. We evaluated three telemedicine apps used in Saudi Arabia using a heuristic evaluation method with a focus on understanding the usability issues in the apps user interface during COVID-19. We identified 54 user interface usability issues that may have an effect on the overall usability. Overall, our findings indicate that the three apps have a room for improvement by enhancing their user interfaces to improve the overall user experience.

Author Contributions: Conceptualization, R.N.A. and J.A.A.; formal analysis, R.N.A., J.A.A. and S.B.; methodology, R.N.A.; project administration, R.N.A.; visualization, S.B.; writing-original draft, R.N.A. and J.A.A.; writing-review and editing, R.N.A., J.A.A. and S.B. All authors have read and agreed to the published version of the manuscript.

Funding: No funding.

Institutional Review Board Statement: This study was approved by the Institutional Review Board at King Saud University.

Informed Consent Statement: Not applicable.

Data Availability Statement: Not applicable.

Acknowledgments: The authors thank King Saud University for their scientific support.

Conflicts of Interest: The authors declare no financial interest and no conflict of interest with respect to the research, authorship, and/or publication of this article.

\section{Appendix A}

Table A1. List of mHealth apps published by NDT [29] in 2020 during the time of our study *

\begin{tabular}{|c|c|c|}
\hline No. & mHealth App & App Summary Description \\
\hline 1 & Seha & $\begin{array}{l}\text { Developed by the Ministry of Health }(\mathrm{MOH}) \text { providing health and preventive care through audio-video } \\
\text { medical consultations by } \mathrm{MOH}^{\prime} \text { s specialists, and through artificial intelligence technologies. }\end{array}$ \\
\hline 2 & Mawid & $\begin{array}{c}\text { Developed by the Ministry of Health }(\mathrm{MOH}) \text {, to enable patient to book their appointments across } \\
\text { primary health care centers and manage them by canceling or rescheduling. As well as managing their } \\
\text { referral appointments. }\end{array}$ \\
\hline 3 & Asefni & $\begin{array}{c}\text { Developed by the Saudi Red Crescent Authority providing ambulance emergency services in } \\
\text { Saudi Arabia }\end{array}$ \\
\hline 4 & Dr. Suliman Alhabib & $\begin{array}{l}\text { Developed by Dr. Sulaiman Al Habib Medical Services Group providing access to patient portal } \\
\text { services (such as managing medical records, checking lab results and radiology reports, booking } \\
\text { appointments, checking prescriptions) and telemedicine care. }\end{array}$ \\
\hline 5 & Cura & Developed by Ubieva providing healthcare services $24 / 7$ from a distance. \\
\hline 6 & Kingdom Hospital & $\begin{array}{l}\text { Developed by the Kingdom Hospital providing patient portal services (such as managing medical } \\
\text { records, checking lab results and radiology reports, booking appointments, checking prescriptions). }\end{array}$ \\
\hline 7 & Web Teb & $\begin{array}{c}\text { Developed by Web Teb proving health and medical news and accurate health information } \\
\text { for consumers. }\end{array}$ \\
\hline 8 & Nahdi & $\begin{array}{l}\text { Developed by Al Nahdi Medical Company as a pharmacy app delivering pharmaceutical needs } \\
\text { to customers. }\end{array}$ \\
\hline 9 & Al dawaa Pharmacies & $\begin{array}{l}\text { Developed by Al-Dawaa Medical Services Co as a pharmacy app delivering pharmaceutical needs } \\
\text { to customers. }\end{array}$ \\
\hline 10 & $\begin{array}{l}\text { Mouwasat Medical } \\
\quad \text { Services }\end{array}$ & $\begin{array}{l}\text { Developed by Mouwasat Medical Services providing services, which allow patients to book } \\
\text { appointments, choose nearest hospital and required medical specialty. }\end{array}$ \\
\hline
\end{tabular}

* The list of apps included in the NTD document may have since been updated to include more apps. 


\section{Appendix B}

Form used for evaluation, which was filled out independently by each reviewer using Google forms.

App Features

1-Name of app:

- Seha

- Dr. Suliman Alhabib

- Cura

2-Type of patients the application serves

- Private

- Governmental

2-What clinical specialties are provided to the patient?

3-Is there a limit to the number of consultations with the healthcare provider per month?

- Yes

- No

4-Indicate the availability of the below features:

- COVID-19 screening information

- COVID-19 self-assessment tool

- Ability to choose a certain physician

- Ability to see physician details

- Text messaging

- $\quad$ Voice messaging

- Video call

- Ability to attach and send files

- Ability to schedule a tele-consultation

- Ability to receive on demand consultation

- Prescription

- $\quad$ Link to patient medical record

- Ability to view past consultation

- Satisfaction survey

Usability Heuristics Evaluation Based on Nielsen's Heuristics

Please rate each usability heuristics item based on your inspection.

\begin{tabular}{|c|c|c|c|c|c|}
\hline & $\begin{array}{l}\text { 0-May Not Be } \\
\text { a Problem }\end{array}$ & $\begin{array}{l}\text { 1-Cosmetic } \\
\text { Problem Only }\end{array}$ & $\begin{array}{c}\text { 2-Minor } \\
\text { Usability Problem }\end{array}$ & $\begin{array}{c}\text { 3-Major } \\
\text { Usability Problem }\end{array}$ & $\begin{array}{l}\text { 4-Usability } \\
\text { Catastrophe }\end{array}$ \\
\hline \multicolumn{6}{|l|}{ Visibility of system status } \\
\hline \multicolumn{6}{|l|}{$\begin{array}{l}\text { Match between system and the } \\
\text { real world }\end{array}$} \\
\hline \multicolumn{6}{|l|}{ User control and freedom } \\
\hline \multicolumn{6}{|l|}{ Consistency and standards } \\
\hline \multicolumn{6}{|l|}{ Error prevention } \\
\hline \multicolumn{6}{|l|}{ Recognition rather than recall } \\
\hline \multicolumn{6}{|l|}{ Flexibility and efficiency of use } \\
\hline \multicolumn{6}{|l|}{ Esthetic and minimalist design } \\
\hline \multicolumn{6}{|l|}{$\begin{array}{l}\text { Help users recognize, diagnose, } \\
\text { and recover from errors }\end{array}$} \\
\hline Help and documentation & & & & & \\
\hline
\end{tabular}




\section{Appendix C}

Table A2. "Seha" app (versions 1.0.35 and 1.0.36): usability issues identified based on Nielsen's heuristics.

\begin{tabular}{|c|c|c|c|c|c|c|}
\hline$\#$ & Heuristic Item & $\begin{array}{l}\text { Evaluation } \\
\text { Period }\end{array}$ & Usability Issue Description & Location & Rating & $\begin{array}{l}\text { Redesign } \\
\text { Recommendation }\end{array}$ \\
\hline \multirow{3}{*}{1} & \multirow{3}{*}{$\begin{array}{l}\text { Visibility of } \\
\text { system status }\end{array}$} & First (2020) & No identified & & & \\
\hline & & \multirow[t]{2}{*}{ Second (2021) } & $\begin{array}{l}\text { The timer in the consultation } \\
\text { room: unclear what it } \\
\text { reflects. Does it reflect the } \\
\text { user consultation time limit } \\
\text { or the waiting time to see } \\
\text { the physician? }\end{array}$ & $\begin{array}{l}\text { During } \\
\text { consultation }\end{array}$ & 3 & $\begin{array}{l}\text { Add description of timer, } \\
\text { i.e., waiting time to see } \\
\text { physician or } \\
\text { consultation duration. }\end{array}$ \\
\hline & & & $\begin{array}{l}\text { It took a while to load the } \\
\text { consultation page to start } \\
\text { consultation with physician. }\end{array}$ & $\begin{array}{l}\text { Waiting for } \\
\text { physician }\end{array}$ & 1 & $\begin{array}{l}\text { Add a message } \\
\text { indicating "loading". }\end{array}$ \\
\hline 2 & $\begin{array}{l}\text { Match between } \\
\text { system and the } \\
\text { real world }\end{array}$ & First (2020) & $\begin{array}{l}\text { User may not understand } \\
\text { the meaning of "artificial } \\
\text { intelligence" feature named } \\
\text { "Smart Seha" }\end{array}$ & Log in & 1 & $\begin{array}{l}\text { Add a definition of } \\
\text { "Smart Seha" for the user } \\
\text { in lay terms such as an } \\
\text { "electronic tool that helps } \\
\text { you understand your } \\
\text { symptoms and } \\
\text { recommends } \\
\text { some actions". }\end{array}$ \\
\hline
\end{tabular}

Second (2021) None identified

On the "consult physician"

screen- when the user enters

information, chooses "live session", then chooses to cancel after seeing the waiting time, the app doesn't

Consultation esn't initiation go back to the previous screen "consult physician", the app takes the user to the

First (2020) home screen.

t If the user screen goes static, the app does not give a notification to the user that a physician is present in the session and the app automatically ends the consultation without the option of going back to the session.

User control and freedom
The "back" icon in the consultation room takes the user to the home screen and not to the previous page (page where the user entered the consultation details).

Second (2021)
This happens without giving a notification where the back icon will take the user.
Allow the app to send a notification with sound Waiting for to alert the user when a physician 3 physician is present in the session and reply to the user.
The "back" icon and "end consultation" icon have the same functionality.
End of consultation
Change the icon of the icon to show a "home"

Consultation icon rather than an arrow initiation indication "back" - or program the app to go to the previous page instead of the home.
Differentiate between both icons by creating pages that reflect the functionality of the standard icon. 
Table A2. Cont.

\begin{tabular}{|c|c|c|c|c|c|c|}
\hline \# & Heuristic Item & $\begin{array}{l}\text { Evaluation } \\
\text { Period }\end{array}$ & $\begin{array}{l}\text { Usability Issue } \\
\text { Description }\end{array}$ & Location & Rating & $\begin{array}{l}\text { Redesign } \\
\text { Recommendation }\end{array}$ \\
\hline \multirow{3}{*}{4} & \multirow{3}{*}{$\begin{array}{l}\text { Consistency } \\
\text { and adherence } \\
\text { to standards }\end{array}$} & First (2020) & None identified & & & \\
\hline & & \multirow[t]{2}{*}{ Second (2021) } & $\begin{array}{l}\text { Both "Smart Seha" and } \\
\text { "health check" are } \\
\text { artificial intelligence } \\
\text { functionalities and it is } \\
\text { unclear what the } \\
\text { differences between } \\
\text { these services are. }\end{array}$ & $\log$ in & 2 & $\begin{array}{l}\text { Add a description for } \\
\text { each functionality in } \\
\text { the home page. }\end{array}$ \\
\hline & & & $\begin{array}{l}\text { The term "health check" } \\
\text { may also reflect a } \\
\text { tele-consultation with a } \\
\text { physician. }\end{array}$ & Log in & 3 & $\begin{array}{l}\text { Add a description for } \\
\text { each functionality in } \\
\text { the home page. }\end{array}$ \\
\hline \multirow[b]{2}{*}{5} & \multirow[b]{2}{*}{$\begin{array}{l}\text { Error } \\
\text { prevention }\end{array}$} & First (2020) & $\begin{array}{l}\text { + No notification } \\
\text { indicating that if the user } \\
\text { screen is static, the } \\
\text { consultation will end and } \\
\text { will be counted towards } \\
\text { the user's monthly } \\
\text { consultation limit. }\end{array}$ & Waiting for physician & 4 & $\begin{array}{l}\text { Create a notification for } \\
\text { the user upon entering } \\
\text { the chat room, which } \\
\text { indicates that the } \\
\text { consultation session } \\
\text { will end if no response } \\
\text { comes from the user. }\end{array}$ \\
\hline & & Second (2021) & $\begin{array}{l}\text { When the user clicks on } \\
\text { consultation by mistake, } \\
\text { the app does not send a } \\
\text { confirmation message to } \\
\text { the user to start the } \\
\text { consultation. This then } \\
\text { counts as a consultation } \\
\text { limit if the user decides } \\
\text { to leave without seeing } \\
\text { the physician. }\end{array}$ & Consultationinitiation & 3 & $\begin{array}{l}\text { Allow the app to count } \\
\text { active sessions } \\
\text { (interaction between } \\
\text { the physician and } \\
\text { user)-as part of the } \\
\text { monthly consultation } \\
\text { limit and provide a } \\
\text { follow-up on the } \\
\text { experience of the } \\
\text { consultation. }\end{array}$ \\
\hline \multirow{3}{*}{6} & \multirow{3}{*}{$\begin{array}{l}\text { Recognition } \\
\text { rather than } \\
\text { recall }\end{array}$} & \multirow[t]{2}{*}{ First (2020) } & $\begin{array}{l}\text { t Waiting time is only } \\
\text { displayed before } \\
\text { entering the consultation } \\
\text { session room reflecting } \\
\text { the time the user gets } \\
\text { access to the room. } \\
\text { When the user is in the } \\
\text { room, waiting time for } \\
\text { the physician to start the } \\
\text { session is not displayed. }\end{array}$ & Waiting for physician & 2 & $\begin{array}{l}\text { Provide a countdown } \\
\text { timer within the } \\
\text { consultation session } \\
\text { screen showing the } \\
\text { estimated waiting time } \\
\text { for the physician to } \\
\text { join. }\end{array}$ \\
\hline & & & $\begin{array}{l}\text { After the user leaves the } \\
\text { open consultation } \\
\text { session, the icon for } \\
\text { reentering the } \\
\text { consultation is not clear } \\
\text { for the user. }\end{array}$ & During consultation & 3 & $\begin{array}{l}\text { Add "open } \\
\text { consultation" icon with } \\
\text { visible instructions in } \\
\text { every page. }\end{array}$ \\
\hline & & Second (2021) & $\begin{array}{l}\text { When the user goes out } \\
\text { of the consultation room } \\
\text { by mistake, the app does } \\
\text { not show a notification } \\
\text { that "you are in } \\
\text { consultation". }\end{array}$ & During consultation & 3 & $\begin{array}{l}\text { Show a notification to } \\
\text { user "you are in } \\
\text { consultation". }\end{array}$ \\
\hline 7 & $\begin{array}{l}\text { Flexibility and } \\
\text { efficiency of use }\end{array}$ & $\begin{array}{l}\text { No accelerato } \\
\text { were found. }\end{array}$ & bility to tailor frequent & ns based on inexpe & iced ar & xperienced users \\
\hline
\end{tabular}


Table A2. Cont.

\begin{tabular}{|c|c|c|c|c|c|c|}
\hline$\#$ & Heuristic Item & $\begin{array}{l}\text { Evaluation } \\
\text { Period }\end{array}$ & Usability Issue Description & Location & Rating & $\begin{array}{l}\text { Redesign } \\
\text { Recommendation }\end{array}$ \\
\hline \multirow{3}{*}{8} & \multirow{3}{*}{$\begin{array}{l}\text { Esthetic and } \\
\text { minimalist } \\
\text { design }\end{array}$} & \multirow[b]{2}{*}{ First (2020) } & $\begin{array}{l}\text { Irrelative and unclear icons } \\
\text { shown at the end after the } \\
\text { "consultations page" to view } \\
\text { the history of consultations } \\
\text { indicating "closed". This } \\
\text { icon is "action required". }\end{array}$ & $\begin{array}{l}\text { End of } \\
\text { consultation }\end{array}$ & 1 & $\begin{array}{l}\text { Remove the "action } \\
\text { required" icon from the } \\
\text { closed consultations. }\end{array}$ \\
\hline & & & $\begin{array}{l}\text { There are two icons that lead } \\
\text { to the same function } \\
\text { "starting the telemedicine } \\
\text { consultation". One accessed } \\
\text { in the home screen } \\
\text { "consultations" and the other } \\
\text { in consultations "new", } \\
\text { which brings the user back } \\
\text { to the home screen. }\end{array}$ & $\begin{array}{l}\text { Consultation } \\
\text { initiation }\end{array}$ & 1 & $\begin{array}{l}\text { Remove the "new" tab } \\
\text { from the consultations } \\
\text { screen. Main dashboard } \\
\text { might provide a } \\
\text { summary of the features } \\
\text { offered on a high-level. }\end{array}$ \\
\hline & & Second (2021) & None identified & & & \\
\hline \multirow{2}{*}{9} & \multirow{2}{*}{$\begin{array}{l}\text { Recognition } \\
\text { diagnosis, and } \\
\text { recovery from } \\
\text { errors }\end{array}$} & First (2020) & None identified & & & \\
\hline & & Second (2021) & None identified & & & \\
\hline \multirow[t]{2}{*}{10} & \multirow[t]{2}{*}{$\begin{array}{l}\text { Help and } \\
\text { documentation }\end{array}$} & First (2020) & $\begin{array}{l}\text { Quick start guide is only } \\
\text { displayed to the users when } \\
\text { the app is opened for the } \\
\text { first time. }\end{array}$ & $\log$ in & 3 & $\begin{array}{l}\text { Provide users with } \\
\text { ongoing access to help } \\
\text { through an icon or tab } \\
\text { placed in the chat room } \\
\text { and/or in the home } \\
\text { screen as } \\
\text { user instructions. }\end{array}$ \\
\hline & & Second (2021) & $\begin{array}{l}\text { The app does not provide } \\
\text { clear directions on how to } \\
\text { use the app, and what each } \\
\text { icon or label means. }\end{array}$ & Orientation & 4 & $\begin{array}{l}\text { Provide any extra } \\
\text { information that would } \\
\text { be useful to users, along } \\
\text { with the label. }\end{array}$ \\
\hline
\end{tabular}

Total Issues identified from the two evaluations: 18

† The issue was resolved-no longer identified in our second evaluation.

Table A3. "Cura” app (versions 1.8.9 and 2.0.0): usability issues identified based on Nielsen's heuristics.

\begin{tabular}{|c|c|c|c|c|c|c|}
\hline$\#$ & Heuristic Item & $\begin{array}{l}\text { Evaluation } \\
\text { Period }\end{array}$ & Usability Issue Description & Location & Rating & $\begin{array}{l}\text { Redesign } \\
\text { Recommendation }\end{array}$ \\
\hline \multirow{2}{*}{1} & \multirow{2}{*}{$\begin{array}{l}\text { Visibility of } \\
\text { system status }\end{array}$} & First (2020) & None identified & & & \\
\hline & & Second (2021) & None identified & & & \\
\hline \multirow[t]{2}{*}{2} & \multirow[t]{2}{*}{$\begin{array}{l}\text { Match between } \\
\text { system and the } \\
\text { real world }\end{array}$} & First (2020) & $\begin{array}{l}\text { User may not comprehend } \\
\text { the meaning of "instant } \\
\text { consultation" vs. } \\
\text { "specialized consultation" } \\
\text { and "find a doctor" vs. } \\
\text { "instant consultation" vs. } \\
\text { "specialized consultation" in } \\
\text { a tele-consultation setting. }\end{array}$ & $\begin{array}{l}\text { Consultation } \\
\text { initiation }\end{array}$ & 1 & $\begin{array}{l}\text { Help the user decide } \\
\text { and select the option } \\
\text { that fits their needs. } \\
\text { For example, users } \\
\text { start with "instant } \\
\text { consultation" and } \\
\text { from there they can } \\
\text { be referred to a } \\
\text { specialist if needed. }\end{array}$ \\
\hline & & Second (2021) & None identified & & & \\
\hline
\end{tabular}


Table A3. Cont.

\begin{tabular}{|c|c|c|c|c|c|c|}
\hline$\#$ & Heuristic Item & $\begin{array}{l}\text { Evaluation } \\
\text { Period }\end{array}$ & Usability Issue Description & Location & Rating & $\begin{array}{l}\text { Redesign } \\
\text { Recommendation }\end{array}$ \\
\hline \multirow[t]{2}{*}{3} & \multirow[t]{2}{*}{$\begin{array}{l}\text { User control } \\
\text { and freedom }\end{array}$} & First (2020) & $\begin{array}{l}\text { t No exit icon or skip from } \\
\text { the instructions page when } \\
\text { the user clicks the icon (i). } \\
\text { The user must go through all } \\
\text { the instructions. }\end{array}$ & Orientation & 2 & $\begin{array}{l}\text { Provide a skip icon to } \\
\text { end the } \\
\text { help instructions. }\end{array}$ \\
\hline & & Second (2021) & None identified & & & \\
\hline \multirow{3}{*}{4} & \multirow{3}{*}{$\begin{array}{l}\text { Consistency } \\
\text { and adherence } \\
\text { to standards }\end{array}$} & \multirow[b]{2}{*}{ First (2020) } & $\begin{array}{l}\text { The search for "find a } \\
\text { doctor" is not clear if the } \\
\text { user is searching for the } \\
\text { "specialized consultation" or } \\
\text { the "instant consultation". }\end{array}$ & $\begin{array}{l}\text { Consultation } \\
\text { initiation }\end{array}$ & 3 & $\begin{array}{l}\text { Create separate } \\
\text { search lists based on } \\
\text { the user's choice. }\end{array}$ \\
\hline & & & $\begin{array}{l}\text { On the technical support } \\
\text { page, the license number of } \\
\text { some staff indicates "000" or } \\
\text { other numbers. This is } \\
\text { unclear to the user if it is not } \\
\text { applicable, or the license } \\
\text { number is not updated. }\end{array}$ & Orientation & 3 & $\begin{array}{l}\text { Avoid using " } 000 \text { " } \\
\text { and clearly indicate if } \\
\text { the license number } \\
\text { does not apply to } \\
\text { certain staff. }\end{array}$ \\
\hline & & Second (2021) & $\begin{array}{l}\text { There are some pages } \\
\text { displaying "instant } \\
\text { consultation" and others } \\
\text { displaying "specialized } \\
\text { consultation". }\end{array}$ & Consultationinitiation & 2 & $\begin{array}{l}\text { Standardize the } \\
\text { terms or add a } \\
\text { description under } \\
\text { each term to indicate } \\
\text { the difference } \\
\text { in service. }\end{array}$ \\
\hline \multirow[t]{2}{*}{5} & \multirow[t]{2}{*}{$\begin{array}{l}\text { Error } \\
\text { prevention }\end{array}$} & First (2020) & $\begin{array}{l}\text { "Short brief about your case" } \\
\text { indicates between brackets } \\
\text { as (optional) when in fact it } \\
\text { is mandatory to proceed to } \\
\text { session payment. }\end{array}$ & $\begin{array}{l}\text { Consultation } \\
\text { initiation }\end{array}$ & 3 & $\begin{array}{l}\text { Remove the word } \\
\text { "optional". }\end{array}$ \\
\hline & & Second (2021) & None identified & & & \\
\hline \multirow[t]{2}{*}{6} & \multirow[t]{2}{*}{$\begin{array}{l}\text { Recognition } \\
\text { rather than } \\
\text { recall }\end{array}$} & First (2020) & $\begin{array}{l}\text { † On the "search for doctor" } \\
\text { screen" the user may not } \\
\text { recall what each doctor } \\
\text { specialty icon on the left } \\
\text { panel represents and the } \\
\text { user may need to click on } \\
\text { each icon to read the labels } \\
\text { presented on the right panel. }\end{array}$ & $\begin{array}{l}\text { Consultation } \\
\text { initiation }\end{array}$ & 2 & $\begin{array}{l}\text { Help users select the } \\
\text { doctor specialty } \\
\text { based on symptoms } \\
\text { or area of body in the } \\
\text { main page instead of } \\
\text { browsing all } \\
\text { doctor specialties. }\end{array}$ \\
\hline & & Second (2021) & $\begin{array}{l}\text { There is no specific icon that } \\
\text { represents "help". Help } \\
\text { videos are displayed with } \\
\text { other information under } \\
\text { "find doctor" tab. }\end{array}$ & Orientation & 3 & $\begin{array}{l}\text { Add an icon } \\
\text { representing "help" } \\
\text { where users can } \\
\text { easily recall. }\end{array}$ \\
\hline 7 & $\begin{array}{l}\text { Flexibility and } \\
\text { efficiency of use }\end{array}$ & \multicolumn{5}{|c|}{$\begin{array}{l}\text { No accelerators or ability to tailor frequent actions based on inexperienced and experienced users } \\
\text { were found. }\end{array}$} \\
\hline
\end{tabular}


Table A3. Cont.

\begin{tabular}{|c|c|c|c|c|c|c|}
\hline$\#$ & Heuristic Item & $\begin{array}{l}\text { Evaluation } \\
\text { Period }\end{array}$ & Usability Issue Description & Location & Rating & $\begin{array}{l}\text { Redesign } \\
\text { Recommendation }\end{array}$ \\
\hline \multirow[t]{2}{*}{8} & \multirow[t]{2}{*}{$\begin{array}{l}\text { Esthetic and } \\
\text { minimalist } \\
\text { design }\end{array}$} & First (2020) & $\begin{array}{l}\text { The main "search for doctor" } \\
\text { screen displays too much } \\
\text { information in one screen } \\
\text { i.e., name of doctor, picture, } \\
\text { title, specialty, and rating. }\end{array}$ & $\begin{array}{l}\text { Consultation } \\
\text { initiation }\end{array}$ & 1 & $\begin{array}{l}\text { The name of specialty } \\
\text { may be removed } \\
\text { since it is indicated } \\
\text { under the main } \\
\text { screen heading. } \\
\text { Rating can also be } \\
\text { removed as it is } \\
\text { shown when the user } \\
\text { clicks on a specific } \\
\text { doctor. }\end{array}$ \\
\hline & & Second (2021) & $\begin{array}{l}\text { There is a tab to "find a } \\
\text { doctor" and there is also the } \\
\text { same tab under "clinic". } \\
\text { "Find doctor" tab includes } \\
\text { several irrelevant } \\
\text { information }\end{array}$ & $\begin{array}{l}\text { Consultation } \\
\text { initiation } \\
\text { Consultation } \\
\text { initiation }\end{array}$ & $\begin{array}{l}3 \\
4\end{array}$ & $\begin{array}{l}\text { Remove the } \\
\text { additional tab which } \\
\text { is under the clinic. } \\
\text { Only include } \\
\text { information relevant } \\
\text { to "find doctor" }\end{array}$ \\
\hline
\end{tabular}

\begin{tabular}{|c|c|c|c|c|c|c|}
\hline \multirow{2}{*}{9} & \multirow{2}{*}{$\begin{array}{l}\text { Recognition } \\
\text { diagnosis, and } \\
\text { recovery from } \\
\text { errors }\end{array}$} & First (2020) & \multicolumn{4}{|l|}{ None identified } \\
\hline & & Second (2021) & None identified & & & \\
\hline \multirow[t]{2}{*}{10} & \multirow[t]{2}{*}{$\begin{array}{l}\text { Help and } \\
\text { documentation }\end{array}$} & First (2020) & $\begin{array}{l}\text { The location of where the } \\
\text { support and help are } \\
\text { displayed in the app (part of } \\
\text { the doctor list) may confuse } \\
\text { the user. } \\
\text { t The icon (i) representing } \\
\text { help may be confused with } \\
\text { general information about } \\
\text { the app. }\end{array}$ & $\begin{array}{l}\text { Orientation } \\
\text { Orientation }\end{array}$ & $\begin{array}{l}1 \\
2\end{array}$ & $\begin{array}{l}\text { It should be under a } \\
\text { separate help icon. } \\
\text { Change the icon } \\
\text { (i) to "help" }\end{array}$ \\
\hline & & Second (2021) & $\begin{array}{l}\text { Difficult to retrieve the help } \\
\text { page when a consultation } \\
\text { with the physician } \\
\text { is ongoing. }\end{array}$ & During consultation & 4 & $\begin{array}{l}\text { Add a clear separate } \\
\text { page with a help icon, } \\
\text { which can } \\
\text { be accessible. }\end{array}$ \\
\hline
\end{tabular}

Total Issues identified from the two evaluations: 14

† The issue was resolved-no longer identified in our second evaluation.

Table A4. “Dr. Sulaiman Alhabib" app (versions 4.2.3 and 4.4.4): usability issues identified based on Nielsen's heuristics.

\begin{tabular}{|c|c|c|c|c|c|c|}
\hline$\#$ & Heuristic Item & $\begin{array}{l}\text { Evaluation } \\
\text { Period }\end{array}$ & Usability Issue Description & Location & Rating & $\begin{array}{l}\text { Redesign } \\
\text { Recommendation }\end{array}$ \\
\hline \multirow[b]{2}{*}{1} & \multirow[b]{2}{*}{$\begin{array}{l}\text { Visibility of } \\
\text { system status }\end{array}$} & First (2020) & $\begin{array}{l}\text { The app does not provide } \\
\text { enough feedback after } \\
\text { pressing the start } \\
\text { consultation button. }\end{array}$ & $\begin{array}{l}\text { Consultation } \\
\text { initiation }\end{array}$ & 1 & $\begin{array}{l}\text { Provide constructive } \\
\text { feedback describing } \\
\text { what the system } \\
\text { is doing. }\end{array}$ \\
\hline & & Second (2021) & $\begin{array}{l}\text { Loading time was long. } \\
\text { Does not indicate what the } \\
\text { app is doing from one page to } \\
\text { another, just shows the } \\
\text { hospital logo. }\end{array}$ & $\begin{array}{l}\text { Consultation } \\
\text { initiation } \\
\text { Orientation }\end{array}$ & $\begin{array}{l}1 \\
2\end{array}$ & $\begin{array}{l}\text { Add a message } \\
\text { indicating "loading". } \\
\text { Provide constructive } \\
\text { feedback describing } \\
\text { what the } \\
\text { system is doing. }\end{array}$ \\
\hline
\end{tabular}


Table A4. Cont.

\begin{tabular}{|c|c|c|c|c|c|c|}
\hline$\#$ & Heuristic Item & $\begin{array}{l}\text { Evaluation } \\
\text { Period }\end{array}$ & Usability Issue Description & Location & Rating & $\begin{array}{l}\text { Redesign } \\
\text { Recommendation }\end{array}$ \\
\hline \multirow[t]{2}{*}{2} & \multirow{2}{*}{$\begin{array}{l}\text { Match between } \\
\text { system and the } \\
\text { real world }\end{array}$} & First (2020) & $\begin{array}{l}\text { When registering as a new } \\
\text { patient, the app mandates the } \\
\text { name in English. }\end{array}$ & Registration & 2 & $\begin{array}{l}\text { Allow the user to } \\
\text { choose the name in } \\
\text { Arabic or English. }\end{array}$ \\
\hline & & Second (2021) & None identified & & & \\
\hline \multirow[t]{2}{*}{3} & \multirow[t]{2}{*}{$\begin{array}{l}\text { User control } \\
\text { and freedom }\end{array}$} & First (2020) & $\begin{array}{l}\text { In the payment screen, when } \\
\text { user wants to change method } \\
\text { of payment, the back icon } \\
\text { takes the user to the home } \\
\text { screen to start over and not } \\
\text { back to the payment } \\
\text { method options. } \\
\text { t The session starts a video } \\
\text { directly without the } \\
\text { patient's consent. }\end{array}$ & $\begin{array}{l}\text { Consultation } \\
\text { initiation } \\
\text { During } \\
\text { consultation }\end{array}$ & $\begin{array}{l}2 \\
4\end{array}$ & $\begin{array}{l}\text { Allow the user to go } \\
\text { back to the previous } \\
\text { payment method } \\
\text { screen instead of the } \\
\text { home screen. } \\
\text { Notify the patient that } \\
\text { the session will start in } \\
\text { video or start with a } \\
\text { voice call and then } \\
\text { with video after } \\
\text { patient approval. }\end{array}$ \\
\hline & & Second (2021) & $\begin{array}{l}\text { The app allows the users to } \\
\text { search the schedules of } \\
\text { physicians before logging in. } \\
\text { After the user has chosen a } \\
\text { time, the app displays a } \\
\text { message to the user to logs in. } \\
\text { When the user login, the app } \\
\text { returns the user to the home } \\
\text { screen to search again. }\end{array}$ & $\begin{array}{l}\text { Consultation } \\
\text { initiation }\end{array}$ & 2 & $\begin{array}{l}\text { Ask the user to log in } \\
\text { before searching the } \\
\text { schedules of physicians } \\
\text { or prevent the app } \\
\text { from going back to the } \\
\text { first step (home screen) } \\
\text { after the user logs in. }\end{array}$ \\
\hline
\end{tabular}

Make the live care icon

† How to access the telemedicine service from the home page is unclear to the user, i.e., what is the difference between the live care icon and the request appointment icon. more visible to the user by creating an option Consultation to choose from a list of initiation 2 consultation types, e.g. telemedicine-live, or physical visit by appointment and adherence to standards

$$
\text { Second (2021) }
$$

After selecting" live care", there are two tabs: "consultation" and "name of the doctor", which confuse the user.

\begin{tabular}{ll}
\hline & When registering as a new \\
& patient, the app does not \\
indicate the name in English \\
as a requirement. \\
t No confirmation message for \\
the user to end the session.
\end{tabular}

5 Error prevention

\section{The app did not provide an} error prevention message

Second (2021) during log in stage. In general, the app did not provide any error prevention messages.

$\begin{array}{lll}\begin{array}{l}\text { Consultation } \\ \text { initiation }\end{array} & 3 & \begin{array}{l}\text { Add a description } \\ \text { under each tab }\end{array}\end{array}$

Inform the user or provide an early error Registration message when Arabic End of letters are written. consultation 2 Show a confirmation message before ending the session.

Add notification messages throughout the app, indicating and error will occur if the user proceeds or clicks a certain tab or icon. 
Table A4. Cont.

\begin{tabular}{|c|c|c|c|c|c|c|}
\hline$\#$ & Heuristic Item & $\begin{array}{l}\text { Evaluation } \\
\text { Period }\end{array}$ & Usability Issue Description & Location & Rating & $\begin{array}{l}\text { Redesign } \\
\text { Recommendation }\end{array}$ \\
\hline \multirow[t]{2}{*}{6} & \multirow[t]{2}{*}{$\begin{array}{l}\text { Recognition } \\
\text { rather than } \\
\text { recall }\end{array}$} & First (2020) & $\begin{array}{l}\text { † No instructions on how to } \\
\text { use the app. }\end{array}$ & $\begin{array}{l}\text { During } \\
\text { consultation }\end{array}$ & 4 & $\begin{array}{l}\text { Provide the user with } \\
\text { clear instruction before } \\
\text { the start of the live } \\
\text { care session. }\end{array}$ \\
\hline & & Second (2021) & None identified & & & \\
\hline 7 & $\begin{array}{l}\text { Flexibility and } \\
\text { efficiency of use }\end{array}$ & \multicolumn{5}{|c|}{$\begin{array}{l}\text { No accelerators or ability to tailor frequent actions based on inexperienced and experienced users } \\
\text { were found. }\end{array}$} \\
\hline
\end{tabular}

The home page dashboard has so many displayed icons, which may confuse the user. The live session screen has First (2020) icons placed in the bottom panel that may not be needed during the live consultation appointment" and "actions".

minimalist design session such as "book

\section{"My Medical File" tab has}

Second (2021) many icons, which may confuse the user, when accessing records.
Design a more minimalist and esthetic home screen.

Remove "book appointment" and "actions" icons from the live session screen.

Minimize the icons and information displayed, by allowing the patient to personalize the page.

Add real-time updates indicating the available clinics (currently online) vs. unavailable because of choosing an unavailable clinic does not

First (2020) show a recovery message that

\section{Consultation} initiation the clinic has ended. The user must close the application and start over.

clinics (offline) and provide a message to the user indicating what to do in case he/she chooses an unavailable clinic.

Add clear error
messages associated

The error presented to the user was not clear and did not explain the error and

Consultation initiation the solution on how to resolve the with clear instructions error

Provide users with easy access to instructions on how to use the app and on the "live care" feature are not presented to the user with no technical support contact information in case the user needs assistance.
Help and

10 documentation
First (2020)
Instructions on how to access the help giving instructions on how to use the "live care" feature are not clear to the user. Voice recognition help is not appropriately working.
Orientation 4

home screen as user instructions.

Provide contacts for help and support or live chat for technical issues.

Add a clear separate page with a help icon,
Orientation during consultation
2

4 explaining how the app is used. Improve or remove the feature.

Total Issues identified from the two evaluations: 22 


\section{References}

1. World Health Organization. WHO Coronavirus (COVID-19) Dashboard. Available online: https://covid19.who.int (accessed on 27 September 2021).

2. Monaghesh, E.; Hajizadeh, A. The role of telehealth during COVID-19 outbreak: A systematic review based on current evidence. BMC Public Health 2020, 20, 1193. [CrossRef]

3. John Leon Singh, H.; Couch, D.; Yap, K. Mobile Health Apps That Help With COVID-19 Management: Scoping Review. JMIR Nurs. 2020, 3, e20596. [CrossRef]

4. Zhai, Y.; Wang, Y.; Zhang, M.; Gittell, J.H.; Jiang, S.; Chen, B.; Cui, F.; He, X.; Zhao, J.; Wang, X. From isolation to coordination: How can telemedicine help combat the COVID-19 outbreak? MedRxiv 2020. [CrossRef]

5. Rabuñal, R.; Suarez-Gil, R.; Golpe, R.; Martínez-García, M.; Gómez-Méndez, R.; Romay-Lema, E.; Pérez-López, A.; RodríguezÁlvarez, A.; Bal-Alvaredo, M. Usefulness of a Telemedicine Tool TELEA in the Management of the COVID-19 Pandemic. Telemed e-Health. 2020, 26, 1332-1335. [CrossRef]

6. Hassounah, M.; Raheel, H.; Alhefzi, M. Digital response during the COVID-19 pandemic in Saudi Arabia. J. Med. Internet Res. 2020, 22, e19338. [CrossRef]

7. Ministry of Health. Sehha. Available online: https://www.moh.gov.sa/en/Support/Pages/MobileApp.aspx (accessed on 27 September 2021).

8. Narasimha, S.; Madathil, K.C.; Agnisarman, S.; Rogers, H.; Welch, B.; Ashok, A.; Nair, A.; McElligott, J. Designing Telemedicine Systems for Geriatric Patients: A Review of the Usability Studies. Telemed. e-Health 2017, 23, 459-472. [CrossRef] [PubMed]

9. Abelson, J.; Li, K.; Wilson, G.; Shields, K.; Schneider, C.; Boesveld, S. Supporting quality public and patient engagement in health system organizations: Development and usability testing of the Public and Patient Engagement Evaluation Tool. Health Expect. 2016, 19, 817-827. [CrossRef] [PubMed]

10. Bestsennyy, O.; Gilbert, G.; Harris, A. Rost. Telehealth: A Quarter-Trillion-Dollar Post-COVID-19 Reality? Available online: https:/ / www.mckinsey.com/industries/healthcare-systems-and-services/our-insights/telehealth-a-quarter-trillion-dollarpost-covid-19-reality (accessed on 17 November 2021).

11. International Organization for Standardization. Usability of Consumer Products and Products for Public Use-Part 2: Summative Test Method. Iso.org. Available online: https://www.iso.org/obp/ui/\#iso:std:iso:ts:20282:-2:ed-2:v1:en (accessed on 2 November 2021).

12. Zapata, B.C.; Fernández-Alemán, J.L.; Idri, A.; Toval, A. Empirical Studies on Usability of mHealth Apps: A Systematic Literature Review. J. Med. Syst. 2015, 39, 1. [CrossRef] [PubMed]

13. Nielsen, J.; Molich, R. Heuristic evaluation of user interfaces. In Proceedings of the SIGCHI Conference on Human Factors in Computing Systems Empowering People-CHI'90, Seattle, WA, USA, 1-5 April 1990; ACM Press: New York, NY, USA, 1990; pp. 249-256. [CrossRef]

14. Agnisarman, S.; Narasimha, S.; Madathil, K.C.; Welch, B.; Brinda, F.; Ashok, A.; McElligott, J.; Alhuwail, D.; Chaudry, B. Toward a More Usable Home-Based Video Telemedicine System: A Heuristic Evaluation of the Clinician User Interfaces of Home-Based Video Telemedicine Systems. JMIR Hum. Factors 2017, 4, e11. [CrossRef] [PubMed]

15. Lilholt, P.H.; Jensen, M.H.; Hejlesen, O.K. Heuristic evaluation of a telehealth system from the Danish TeleCare North Trial. Int. J. Med. Inform. 2015, 84, 319-326. [CrossRef]

16. Tang, Z.; Johnson, T.; Tindall, R.; Zhang, J. Applying Heuristic Evaluation to Improve the Usability of a Telemedicine System. Telemed. e-Health 2006, 12, 24-34. [CrossRef] [PubMed]

17. Ligons, F.M.; Romagnoli, K.M.; Browell, S.; Hochheiser, H.S.; Handler, S.M. Assessing the usability of a telemedicine-based Medication Delivery Unit for older adults through inspection methods. AMIA Annu. Symp. Proc. 2011, 2011, $795-804$.

18. Dourado, M.A.; Canedo, E.D. Usability Heuristics for Mobile Applications-A Systematic Review. In Proceedings of the International Conference on Enterprise Information Systems (ICEIS), Madeira, Portugal, 21-24 March 2018.

19. Virzi, R.A. Refining the Test Phase of Usability Evaluation: How Many Subjects Is Enough? Hum. Factors J. Hum. Factors Ergon. Soc. 1992, 34, 457-468. [CrossRef]

20. Nielsen, J.; Landauer, T.K. A mathematical model of the finding of usability problems. In Proceedings of the SIGCHI Conference on Human Factors in Computing Systems-CHI'93, New York, NY, USA, 22-27 April 2006; ACM Press: New York, NY, USA, 1993; pp. 206-213. [CrossRef]

21. National Transformation Program I Saudi Vision 2030. Available online: https://www.vision2030.gov.sa/v2030/vrps/ntp/ (accessed on 27 September 2021).

22. Council of Cooperative Health Insurance. Available online: https:/ / www.cchi.gov.sa/en/Pages/default.aspx (accessed on 27 September 2021).

23. Ekeland, A.G.; Bowes, A.; Flottorp, S. Effectiveness of telemedicine: A systematic review of reviews. Int. J. Med. Inform. 2010, 79, 736-771. [CrossRef]

24. Alshareef, M.; Alsaleh, S.; Albaharna, H.; Alghulikah, A.; Aloulah, M.; Alroqi, A.; Alromaih, S.; Alanazy, F.H.; Al-Dousary, S. Utilization of telemedicine in rhinologic practice during COVID-19 pandemic. Am. J. Otolaryngol. 2021, 42, 102929. [CrossRef] 
25. Al-Sofiani, M.E.; Alyusuf, E.Y.; Alharthi, S.; Alguwaihes, A.M.; Al-Khalifah, R.; Alfadda, A. Rapid Implementation of a Diabetes Telemedicine Clinic During the Coronavirus Disease 2019 Outbreak: Our Protocol, Experience, and Satisfaction Reports in Saudi Arabia. J. Diabetes Sci. Technol. 2021, 15, 329-338. [CrossRef] [PubMed]

26. Tourkmani, A.M.; Alharbi, T.J.; Bin Rsheed, A.M.; Alrasheedy, A.; Almadani, W.; Aljuraisi, F.; Al Otaibi, A.F.; Al Harbi, M.; Al Abood, A.F.; Ibn Alshaikh, A. The impact of telemedicine on patients with uncontrolled type 2 diabetes mellitus during the COVID-19 pandemic in Saudi Arabia: Findings and implications. J. Telemed. Telecare 2021. [CrossRef]

27. Mubaraki, A.A.; Alrabie, A.D.; Sibyani, A.K.; Aljuaid, R.S.; Bajaber, A.S.; Mubaraki, M.A. Advantages and disadvantages of telemedicine during the COVID-19 pandemic era among physicians in Taif, Saudi Arabia. Saudi Med. J. 2021, 42, 110-115. [CrossRef]

28. Ministry of Health. MOH Reports First Case of Coronavirus Infection. Available online: https://www.moh.gov.sa/en/Ministry/ MediaCenter/News/Pages/News-2020-03-02-002.aspx (accessed on 27 September 2021).

29. National Digital Transformation Unit. National Digital Transformation Unit. Available online: https://www.my.gov.sa/wps/ portal/snp/aboutksa/digitaltransformation (accessed on 7 November 2021).

30. National Health Information Center. The Governing Rules of Telehealth (Telemedicine) in Saudi Arabia. Available online: https:/ / nhic.gov.sa/en/Initiatives/Documents/TheGoverningRulesOfTelehealthEnglishEstablishingRules.pdf (accessed on 27 September 2021).

31. Cura Healthcare. Cura App. Available online: https:/ / cura.healthcare/en/ (accessed on 27 September 2021).

32. Dr. Suliman Alhabib. HMG History. Available online: https://hmg.com/en/About-us/History/Pages/projects.aspx (accessed on 27 September 2021).

33. Nielsen, J. Usability inspection methods. In Proceedings of the Conference Companion on Human Factors in Computing Systems, Boston, MA, USA, 24-28 April 1994; pp. 413-414.

34. Google. Google Form. Available online: https:/ /www.google.com/intl/en-GB/forms/about/ (accessed on 27 September 2021).

35. Nielsen, J. Finding usability problems through heuristic evaluation. In Proceedings of the SIGCHI Conference on Human Factors in Computing Systems-CHI'92, Monterey, CA, USA, 3-7 May 1992; ACM Press: New York, NY, USA, 1992; pp. 373-380. [CrossRef]

36. McDonagh, M.; Peterson, K.; Raina, P.; Chang, S.; Shekelle, P. Avoiding Bias in Selecting Studies. In Methods Guide for Effectiveness and Comparative Effectiveness Reviews [Internet]; Agency for Healthcare Research and Quality (US): Rockville, MD, USA, 2008. Available online: https:/ / www.ncbi.nlm.nih.gov/books/NBK126701/ (accessed on 17 November 2021).

37. Ministry of Health. Healthcare Licensing Services. Available online: https://www.moh.gov.sa/en/eServices/Licences/Pages/ default.aspx (accessed on 27 September 2021).

38. Communications, Commission IT. Communications and Information Technology Commission. Available online: https://www. citc.gov.sa/ar/Pages/default.aspx (accessed on 27 September 2021).

39. Saudi Food and Drug Authority. SFDA. Available online: https://www.sfda.gov.sa/en (accessed on 27 September 2021).

40. Saudi Data and AI Authority. SDAIA. Available online: https://sdaia.gov.sa (accessed on 27 September 2021).

41. Saudi Central Board for Accreditation of Healthcare Institutions. CBAHI. Available online: https://portal.cbahi.gov.sa/english/ home (accessed on 27 September 2021).

42. Saudi Commission for Health Specialties. Telemedicine. Available online: https://www.scfhs.org.sa/en/eservices/Practitioners/ Pages/TELE-MEDICINE.aspx (accessed on 27 September 2021).

43. National Health Information Center (NHIC). Telemedicine Regulations in the Kingdom of Saudi Arabia. Available online: https: //nhic.gov.sa/en/Initiatives/Documents/Saudi\%20Arabia\%20Telemedicine\%20Policy.pdf (accessed on 27 September 2021).

44. National Health Information Center. NHIC. Available online: https://nhic.gov.sa/en/Pages/default.aspx (accessed on 27 September 2021).

45. Harbi, A. Health Care Expert's readiness to implement National Unified Medical Records (NUMR) system in the United Arab Emirates: A Qualitative study. Informatica 2021, 45, 687-696. [CrossRef]

46. Wu, R.; Ahn, G.; Hu, H. Secure sharing of electronic health records in clouds. In Proceedings of the 8th International Conference on Collaborative Computing: Networking, Applications and Worksharing (CollaborateCom), Pittsburgh, PA, USA, 14-17 October 2012; pp. 711-718.

47. Zhang, J.; Johnson, T.R.; Patel, V.L.; Paige, D.L.; Kubose, T. Using usability heuristics to evaluate patient safety of medical devices. J. Biomed. Inform. 2003, 36, 23-30. [CrossRef]

48. Triana, A.J.; Gusdorf, R.E.; Shah, K.P.; Horst, S.N. Technology Literacy as a Barrier to Telehealth During COVID-19. Telemed. e-Health 2020, 26, 1118-1119. [CrossRef] [PubMed]

49. Wharton, C.; Rieman, J.; Lewis, C.; Polson, P. The cognitive walkthrough method: A practitioner's guide. In Usability Inspection Methods; Nielsen Norman Group: Fremont, CA, USA, 1994; Available online: https://www.colorado.edu/ics/sites/default/ files/attached-files/93-07.pdf (accessed on 17 November 2021).

50. Alonso-Ríos, D.; Mosqueira-Rey, E.; Moret-Bonillo, V. A Systematic and Generalizable Approach to the Heuristic Evaluation of User Interfaces. Int. J. Hum.-Comput. Interact. 2017, 34, 1-14. [CrossRef] 